\section{JURNAL PARSPRINIII Lurnal Käilan Sosioloni dan Pandidikan}

Jurnal Perspektif: Jurnal Kajian Sosiologi dan Pendidikan Vol. 2 No. 1 Tahun 2019

http://perspektif.ppj.unp.ac.id

Email: perspektif@ppj.unp.ac.id

ISSN: 2622-1748 (Online), 2684-902X (Print)

DOI: http://dx.doi.org/10.24036/perspektif.v2i1.58

\title{
Perilaku Siswa Menghadapi Ujian Nasional Berbasis Komputer di SMAN 3 Kota Pariaman Tahun 2018
}

\author{
Nadia Muspita Sari', Erianjoni Erianjoni ${ }^{2}$, Ike Sylvia ${ }^{3}$ \\ 1,2,3Universitas Negeri Padang \\ email: nadiamuspita1@gmail.com, erian_joni@yahoo.com ikesylvia@fis.unp.ac.id
}

\begin{abstract}
Abstrak
Penelitian ini bertujuan untuk mengetahui perilaku siswa menghadapi Ujian Nasional Berbasis Komputer di SMAN 3 Kota Pariaman tahun 2018. Penelitian ini dianalisis dengan teori atribusi yang dikemukakan oleh Fritz Heider. Penelitian ini menggunakan pendekatan kualitatif tipe deskriptif, teknik pemilihan informan purposive sampling dengan jumlah informan 41 orang. Pengumpulan data dilakukan dengan cara observasi, wawancara, dan dokumentasi yang dianalisis dengan mengunakan teknik analisis data dari Miles dan Huberman. Hasil penelitian menunjukan bahwa perilaku siswa dikelompokan menjadi dua yaitu perilaku positif dan perilaku negatif. Perilaku positif terdiri dari perilaku valisional, perilaku aktif, perilaku normatif, dan perilaku mandiri pada saat UNBK berlangsung. Perilaku positif ditunjukan oleh mayoritas siswa berasal dari jurusan IPA yang dibuktikan hasil UNBK lebih tinggi dan lebih banyak diterima di perguruan tinggi. Perilaku ini didominasi oleh kekuatan atribusi internal. Sedangkan perilaku negatif terdiri dari; perilaku stereotip, perilaku pasif, perilaku menyimpang, dan perilaku bergantung kepada orang lain. Perilaku ini ditunjukan oleh mayoritas siswa jurusan IPS yang dibuktikan hasil UNBK rendah dan sedikit diterima di perguruan tinggi. Perilaku ini didominasi oleh kekuatan atribusi eksternal.
\end{abstract}

Kata Kunci: Perilaku, Siswa, UNBK

\begin{abstract}
This study aims to determine the behaviorof students facing the Computer National Examination at SMAN 3 Kota Pariaman in 2018. This research was analyzed by the attribution theory proposed by Fritz Heider. This study uses a gualitatie type approach descriptive, informant selection technique purposive sampling with the number of informants 41 people. Data collection by observation interviews and documentation analyzed by using data analysis techniques from Miles and Huberman. The results of the study show that student grouped two behavior is positive behaviors and negative behavior. Positive behavior; valitional behavior, active behavior, normative behavior and Independent behavior at UNBK take place. Positive behavior shown by the majority of students from science departements proved that the result of UNBK were higher and more accepted in higher education. This behavior is dominated by the power of internal attribution. Whereas negative behavior consists of; stereotypical behavior, passive behavior, deviant behavior, and behavior depend on others. This behavior is shown by the majority of students majoring in social studies who are proven to have low UNBK results and are slightly accepted in higher education. This behavior is dominated by the power of external attribution.
\end{abstract}

Keywords: Behavior, Students, UNBK 


\section{Pendahuluan}

Pendidikan adalah hal pokok yang menopang kemajuan suatu bangsa. Kemajuan suatu bangsa diukur dari kualitas dan sistem pendidikan yang ada. Tanpa pendidikan, suatu negara akan jauh tertinggal dengan negara lain. Salah satu cara mengukur kualitas pendidikan di Indonesia yaitu melalui Ujian Nasional (UN). Hasil Ujian Nasional dapat digunakan untuk pemetaan mutu program pendidikan dan satuan pendidikan, pertimbangan seleksi untuk melanjutkan ke jenjang pendidikan berikutnya, dasar pembinaan dan pemberian bantuan kepada satuan pendidikan untuk pemerataan serta peningkatan mutu pendidikan. Pada tahun 2015 adanya kebijakan pemerintah untuk melaksanakan Ujian Nasional Berbasisi Komputer (UNBK) di SMP, SMA/MA/SMK di Indonesia.

Pelaksanaan UNBK di Kota Pariaman pada tahun 2017 dilaksanakan oleh lima Sekolah Menengah Atas (SMA) dan enam Sekolah Menengah Kejurusan (SMK). Adapun SMA yang melaksanakan UNBK adalah sebagai berikut; SMA Negeri 1 Pariaman, SMA Negeri 2 Pariaman, SMA Negeri 3 Pariaman, SMA Negeri 4 Pariaman, dan SMA Negeri 5 Pariaman. Hasil UNBK SMAN 3 Pariaman jurusan IPA dan IPS akan dijelaskan pada tabel di bawah ini.

Tabel 1. Nilai UNBK Jurusan IPA SMA se- Kota Pariaman Tahun 2017

\begin{tabular}{|c|c|c|c|c|c|c|c|c|c|}
\hline \multirow[b]{2}{*}{ No } & \multirow[b]{2}{*}{$\begin{array}{c}\text { Nama } \\
\text { Sekolah }\end{array}$} & \multirow[b]{2}{*}{$\begin{array}{c}\text { Jumlah } \\
\text { Siswa }\end{array}$} & \multicolumn{7}{|c|}{ Nilai } \\
\hline & & & $\begin{array}{c}\text { Bahasa } \\
\text { Indonesia }\end{array}$ & $\begin{array}{l}\text { Bahasa } \\
\text { Inggris }\end{array}$ & $\begin{array}{c}\text { Matem } \\
\text { atika }\end{array}$ & $\begin{array}{c}\text { Ekono } \\
\text { mi }\end{array}$ & $\begin{array}{c}\text { Sosio } \\
\text { logi }\end{array}$ & $\begin{array}{c}\text { Geog } \\
\text { rafi }\end{array}$ & $\begin{array}{l}\text { Rata- } \\
\text { Rata }\end{array}$ \\
\hline 1. & $\begin{array}{l}\text { SMAN } 1 \\
\text { Pariaman }\end{array}$ & 85 & 71,15 & 50,68 & 48,91 & 64,13 & 70,05 & $\begin{array}{c}67,0 \\
6\end{array}$ & 61,99 \\
\hline 2. & $\begin{array}{l}\text { SMAN } 2 \\
\text { Pariaman }\end{array}$ & 101 & 63,15 & 35,43 & 32,75 & 48,13 & 63,17 & $\begin{array}{c}51,7 \\
7\end{array}$ & 49,06 \\
\hline 3. & $\begin{array}{l}\text { SMAN } 3 \\
\text { Pariaman }\end{array}$ & 176 & 64,10 & 32,74 & 36,04 & 48,42 & 57,76 & $\begin{array}{c}45,7 \\
6\end{array}$ & 47,47 \\
\hline 4. & $\begin{array}{l}\text { SMAN } 4 \\
\text { Pariaman }\end{array}$ & 142 & 50,70 & 29,85 & 30,26 & 60,50 & 55,96 & - & 45,45 \\
\hline 5. & $\begin{array}{l}\text { SMAN } 5 \\
\text { Pariaman }\end{array}$ & 99 & 60,34 & 33,62 & 31,01 & 46,94 & 53,80 & $\begin{array}{c}46,2 \\
5\end{array}$ & 45,32 \\
\hline
\end{tabular}

(Sumber: PUSKOM Dinas Pendidikan Provinsi Sumatera Barat)

Berdasarkan tabel di atas siswa jurusan IPA di SMA Negeri 1 Pariaman memiliki nilai UNBK lebih tinggi dibandingkan SMAN 2 Pariaman, SMAN 3 Pariaman, SMAN 4 Pariaman dan SMAN 5 Pariaman. SMAN 5 Pariaman memiliki nilai kimia kosong karena tidak ada siswa yang memilih mata pelajaran kimia yang akan diujikan. Siswa yang melaksanakan Ujian Nasional Berbasis Komputer (UNBK) tidak hanya siswa jurusan IPA tetapi juga siswa jurusan IPS. Berikut nilai UNBK siswa jurusan IPS dapat dilihat pada tabel di bawah ini. 
Nadia Muspita Sari, Erianjoni, Ike Sylvia Perilaku Siswa Menghadapi UNBK di SMAN 3 Pariaman Tahun 2018

Tabel 2. Nilai UNBK Jurusan IPS SMA se- Kota Pariaman Tahun 2017

\begin{tabular}{|c|l|c|c|c|c|c|c|c|c|}
\hline No & \multirow{2}{*}{$\begin{array}{c}\text { Nama } \\
\text { Sekolah }\end{array}$} & \multirow{2}{*}{$\begin{array}{c}\text { Jumlah } \\
\text { Siswa }\end{array}$} & $\begin{array}{c}\text { Bahasa } \\
\text { Indonesia }\end{array}$ & $\begin{array}{c}\text { Bahasa } \\
\text { Inggris }\end{array}$ & $\begin{array}{c}\text { Matem } \\
\text { atika }\end{array}$ & Fisika & Kimia & Biologi & $\begin{array}{c}\text { Rata- } \\
\text { Rata }\end{array}$ \\
\hline 1. & $\begin{array}{l}\text { SMAN 1 } \\
\text { Pariaman }\end{array}$ & 171 & 83,63 & 65,03 & 62,56 & 68,71 & 64,43 & 69,91 & 69,55 \\
\hline 2. & $\begin{array}{l}\text { SMAN 2 } \\
\text { Pariaman }\end{array}$ & 156 & 74,91 & 47,23 & 37,79 & 53,37 & 47,88 & 50,98 & 52,03 \\
\hline 3. & $\begin{array}{l}\text { SMAN 3 } \\
\text { Pariaman }\end{array}$ & 117 & 70,66 & 44,75 & 38,82 & 47,68 & 50,53 & 49,48 & 50,32 \\
\hline 4. & $\begin{array}{l}\text { SMAN 4 } \\
\text { Pariaman }\end{array}$ & 164 & 69,65 & 38,62 & 33,14 & 34,29 & 41,25 & 46,23 & 43,86 \\
\hline 5. & $\begin{array}{l}\text { SMAN 5 } \\
\text { Pariaman }\end{array}$ & 73 & 66,63 & 37,75 & 31,13 & 37,50 & - & 40,80 & 42,70 \\
\hline
\end{tabular}

(Sumber: PUSKOM Dinas Pendidikan Provinsi Sumatera Barat)

Berdasarkan tabel di atas siswa jurusan IPS di SMA Negeri 1 Pariaman memiliki nilai UNBK lebih tinggi dibandingkan SMAN 2 Pariaman, SMAN 3 Pariaman, SMAN 4 Pariaman dan SMAN 5 Pariaman. SMAN 4 Pariaman memiliki nilai geografi kosong karena tidak ada siswa yang memilih mata pelajaran geografi yang akan diujikan. Dapat kita lihat dari kedua tabel di atas, hasil Ujian Nasional Berbasis Komputer (UNBK) jurusan IPA dan IPS di SMAN N 3 Pariaman memiliki nilai yang lebih rendah dibandingkan SMAN 1 Pariaman dan SMAN 2 Pariaman padahal ketiga sekolah tersebut sama-sama telah memiliki Akreditasi A.

Penelitian ini bertujuan untuk mengetahui perilaku siswa menghadapi Ujian Nasional Berbasis Komputer (UNBK) di SMAN 3 Kota Pariaman tahun 2018. Penelitian ini di analisis oleh teori atribusi (Attribution Theory) yang dikemukakan oleh Fritz Heider. Menurut (Steers. 1988 dalam Hudayati. 2002) teori Atribusi mempelajari proses bagaimana seseorang mengintrepretasikan suatu peristiwa, mempelajari bagaimana seseorang menginterpretasikan alasan atau sebab perilakunya seseorang itu ditentukan oleh kombinasi antara kekuatan internal (internal forces) yaitu faktor-faktor yang berasal dari dalam diri seseorang misalnya kemampuan, pengetahuan atau usaha, sedangkan kekuatan eksternal (eksternal forces) yaitu faktor-faktor yang berasal dari luar misalnya keberuntungan, kesempatan dan lingkungan.

\section{Metode Penelitian}

Jenis penelitian yang digunakan adalah penelitian kualitatif dengan tipe deskriptif. Menurut Bog dan Taylor dalam (Imron: 1996. 13) mendefinisikan metode penelitian kualitatif sebagai prosedur penelitan yang menghasilkan data deskripsi berupa kata-kata tertulis atau lisan dari orang atau perilaku yang diamati. Metode Deskriptif menurut (Prastowo: 186) adalah suatu metode yang digunakan untuk meneliti status sekelompok manusia, suatu objek, suatu set kondisi, suatu sistem pemikiran, ataupun suatu kelas peristiwa pada masa sekarang. Subjek dalam penelitian ini adalah: Guru, pengawas ujian, panitia UNBK, dan siswa jurusan IPA dan siswa jurusan IPS. Teknik pengambilan data yang digunakan adalah Purposiv sampling atau sampel betujuan dengan jumlah informan 41 orang. Hal ini senada dengan yang dikatakan oleh Miles dan Huberman, dalam (Suwandi: 2008. 54) bahwa peneliti perlu memperhitungkan pengambilan sampel secara purposive yang dijadikan dasar dalam penentuan medan yang mungkin digunakan. Adapun teknik pengumpulan data yang digunakan yaitu wawancara mendalam, observasi, studi pustaka, dan dokumentasi. 
Teknik pengamatan dan observasi menurut (Moleong: 2013) yaitu teknik yang menggunakan pengamatan atau penginderaan langsung terhadap suatu benda, kondisi, situasi, dan proses atau perilaku. Wawancara yang dilakukan menurut (Sugiyono: 2016. 188) adalah wawancara mendalam (in deph-interview) yaitu teknik pengumpulan data yang didasarkan pada percakapan secara intensif dengan menggunakan pedoman wawancara atau catatan yang berisikan pemikiran yang merupakan pertanyaan mendalam yang akan ditanyakan pada waktu wawancara berlangsung. Dokumentasi menurut (Syaodih: 2005. 221) merupakan suatu teknik pengumpulan data dengan menghimpun dan menganalisis dokumen-dokumen, baik dokumen tertulis, gambar maupun elektronik. Penelitian ini dianalisis dengan mengunggunakan teknik analisis data dari Miles dan Huberman (reduksi data, display data, dan penarikan kesimpulan).

\section{Hasil}

Perilaku siswa menghadapi Ujian Nasional Berbasis Komputer (UNBK) terbagi menjadi dua bagian yaitu perilaku sebelum UNBK atau pada saat belajar tambahan dan perilaku siswa pada saat UNBK berlangsung. Perilaku siswa pada saat belajar tambahan dibagi menjadi empat jenis perilaku yaitu perilaku siswa valisional terhadap UNBK, perilaku aktif pada saat belajar tambahan, perilaku stereotip terhadap UNBK, dan perilaku pasif pada saat belajar tambahan.

\section{Perilaku siswa valisional terhadap UNBK}

Perilaku valisional menurut (Jogiyanto: 2007.47) yaitu siswa berperilaku sesuai dengan tujuan yang ingin ia peroleh. Perilaku ini termasuk jnis perilaku terbuka atau perilaku yang dapat dilihat secara langsung. Perilaku siswa valisional terhadap UNBK terwujud dari kehadiran siswa jurusan IPA pada saat belajar tambahan tinggi. Faktor yang mempengaruhi perilaku valisional siswa terhadap UNBK adalah faktor predisposisi yang terwujud dalam pengetahuan, kepercayaan, keyakinan dan dukungan orang tua. Pertama siswa mempunyai persepsi bahwa belajar tambahan akan menambah pengetahuan mereka sehingga dapat menjawab soal UNBK dengan baik. Kedua siswa percaya bahwa UNBK merupakan sesuatu yang sangat penting untuk masa depan pendidikannya. Ketiga siswa yakin bahwa jika mereka serius pada saat belajar tambahan maka ia akan mendapatkan nilai UNBK yang bagus dan diterima di perguruan tinggi yang mereka inginkan. Keempat untuk mencapai tujuannya mereka juga mendapatkan dukungan dari orang tua yaitu mengikuti bimbingan belajar di GAMA dan GO.

Proses pembentukan perilaku siswa valisional terhadap UNBK yakni pembentukan perilaku dengan pengertian (insight) yakni siswa menyadari untuk lulus perguruan tinggi yang mereka inginkan salah satu syaratnya adalah mendapatkan nilai UNBK yang bagus untuk itu mereka harus selalu hadir pada saat belajar tambahan dan serius dalam proses pembelajarn berlangsung. Perilaku ini disebabkan oleh faktor atribusi internal yaitu faktor yang berasal dalam diri siswa sendiri. Siswa jurusan IPA memiliki tujuan untuk mendapatkan nilai UNBK yang tinggi dan diterima di Perguruan Tinggi favorit. Untuk memperoleh tujuan tersebut siswa jurusan IPA tidak hanya mengikuti belajar tambahan di sekolah tetapi juga mengikuti bimbingan belajar di tempat les.

\section{Perilaku siswa aktif pada saat belajar tambahan}

Perilaku aktif menurut (Notoatmodjo: 2014) adalah perilaku terbuka yang dapat diamati secara langsung, berupa tindakan yang nyata seperti mengerjakan soal dan 
melakukan aktivitas lainnya. Perilaku siswa aktif pada saat belajar tambahan terwujud melalui proses belajar yang dilakukan siswa yakni; 1) semangat belajar siswa tinggi, 2) melengakapi alat yang dibutuhkan seperti kalkulator, 3) berdiskusi dengan teman jika jawaban mereka berbeda, 4) siswa bertanya soal yang dianggapnya sulit kepada guru mata pelajaran tertentu, 5) selanjutnya siswa mampu menjawab soal-soal yang diberikan guru. Perilaku aktif yang dilakukan siswa agar mereka mampu menjawab jika soal tersebut keluar pada saat Ujian Nasional Berbasis Komputer (UNBK). Perilaku aktif pada saat belajar tambahan dipengaruhi oleh faktor pendukung adanya fasilitas yang membantu siswa seperti adanya modul soal pada saat belajar biologi dan adanya kalkulator pada saat belajar kimia. Pembentukan perilaku dengan pengertian (insight) yakni siswa memahami bahwa untuk mencapai tujuan dan mempermudah mereka dalam proses pembelajaran maka ia memerlukan modul soal dan kalkulator sehingga mereka memfotokopi modul soal tersebut dan membeli kalkulator.

Perilaku ini disebabkan oleh faktor atribusi internal dan atribusi eksternal yakni lingkungan sosial. Faktor atribusi internal mempengaruhi siswa berperilaku aktif pada saat belajar tambahan karena untuk mencapai tujuannya maka siwa harus aktif pada saat belajar tambahan di sekolah. Faktor atribusi eksternal yakni lingkungan sosial sekolah seperti guru dan teman sekelas, dapat mempengaruhi semangat belajar seorang siswa sehingga menjadi daya dorong yang positif bagi kegiatan belajar siswa belajar dan hasil yang dicapai. Guru memberikan kebebasan kepada siswa dalam mengikuti pembelajaran seperti boleh duduk di lantai, duduk berkelompok, membawa minuman, memakan permen, ngemil, jika tidak mengerti boleh bertanya ke guru tetapi kalau malu bertanya ke guru diperbolehkan bertanya kepada teman yang lebih mengetahui. Proses belajar yang memberikan kenyamanan kepada siswa sehingga siswa terdorong untuk aktif dalam pembelajaran.

\section{Perilaku sterotip siswa terhadap UNBK}

Perilaku stereotipe adalah gambaran tetap yang dibentuk dalam pikiran seseorang mengenai praktik, orang atau fenomena sosial lain atas dasar sikap, pengalaman, nilai, dan juga kesan tanpa ada pengalaman langsung yang akhirnya membentuk berbagai macam perilaku. Perilaku siswa stereotip terhadap UNBK termasuk kedalam bentuk perilaku terbuka yang terwujud dari tingkat kehadiran siswa rendah pada saat belajar tambahan. Perilaku stereotipe dipengaruhi oleh faktor predisposisi. Kehadiran siswa rendah dikarenakan stereotip mereka yang menganggap UNBK hanya sebagai formalitas saja, yang menentukan kelulusan mereka di SMA adalah sekolah dan mereka percaya bahwa sekolah akan meluluskan mereka karena demi nama baik sekolah. Selain itu mereka setelah tamat SMA langsung ingin bekerja, mereka tidak ingin kuliah jadi mereka tidak membutuhkan nilai UNBK yang tinggi. Mereka tidak ingin kuliah dikarenakan mereka memiliki stereotip untuk apa kuliah nanti pada akhirnya juga mencari pekerjaan. Lebih baik saya mencari pekerjaan setelah tamat SMA dari pada membuang waktu untuk kuliah.

Perilaku stereotipe dibentuk dengan cara kebiasaan atau conditioning, kehadiran siswa rendah pada saat belajar tambahan dikarenakan siswa awalnya mencoba tidak datang satu kali kemudian besoknya juga tidak datang karena pergi main dengan teman, besoknya diulang lagi hal ini tentu akan menjadi kebiasaan bagi siswa untuk tidak hadir pada saat belajar tambahan. Sehingga pada saat guru masuk ke dalam kelas hanya tinggal 10-20 orang siswa. Perilaku stereotip disebabkan oleh faktor atribusi eksternal yakni faktor yang berasal dari luar diri siswa seperti pengaruh teman dan pengalaman siswa. Stereotip sekelompok siswa tersebut juga berasal dari pengalaman mereka melihat kakak kelas mereka yang tetap lulus SMA meskipun ia nakal, pemalas, dan sering absen belajar tambahan. 


\section{Perilaku siswa pasif pada saat belajar tambahan}

Perilaku pasif menurut (Kholid: 2012) yaitu perilaku yang sifatnya masih tertutup terjadi dalam diri individu dan tidak dapat diamati secara langsung. Perilaku siswa pasif pada saat belajar tambahan termasuk kedalam bentuk perilaku terbuka yang terwujud melalui proses belajar yang dilakukan siswa yakni; 1) semangat belajar siswa rendah, 2) tidak mau bertanya mengenai soal yang dianggap sulit atau tidak mengerti, 3) sehingga tidak mampu menjawab soal yang diberikan. Perilaku pasif yang dilakukan siswa dipengaruhi oleh faktor faktor pendorong kondisi fisik siswa yang tidak stabil dikarenakan siswa mengantuk, perut lapar, badan lelah, dan metode pembelajaran guru yang membosankan. Selain itu siswa juga memiliki motivasi yang rendah untuk mengikuti belajar tambahan. Perilaku pasif terbentuk karena adanya insight atau pengertian, siswa menyadari bahwa ketika belajar pada waktu sore dimana fisik sudah tidak mendukung seperti lapar, mengantuk, lelah maka otak tidak bisa berfikir dengan baik sehingga proses pembelajaran tidak efektif. Perilaku siswa pasif sangat berhubungan dengan perilaku stereotipe, karena siswa yakin akan tetap lulus SMA dan tidak memiliki keinginan untuk meanjutkan pendidikan ke jenjang berikutnya sehingga mereka berperilaku pasif pada saat belajar tambahan. Perilaku ini disebabkan oleh faktor atribusi internal dan atribusi eksternal. Faktor atribusi internal yaitu disebabkan karena perut lapar, mata mengantuk, jenuh belajar dari pagi. Sedangkan faktor atribusi eksternal disebabkan oleh metode belajar guru yang tidak bervariasi, cuaca yang tidak mendukung, pengaruh teman yang malas dan lain-lain.

Perilaku siswa pada saat Ujian Nasional Berbasis Komputer Berlangsung (UNBK) dibagi menjadi empat jenis perilaku yaitu perilaku normatif siswa terhadap UNBK, perilaku mandiri pada saat ujian berlangsung, perilaku menyimpang terhadap UNBK, dan perilaku bergantung kepada orang lain pada saat ujian.

\section{Perilaku siswa normatif pada saat UNBK}

Perilaku normative menurut (Baumester dan Busman: 2011) adalah perilaku yang diarahkan oleh gagasan-gagasan tertentu yang berkaitan dengan apa yang umumnya dianggap baik atau dikehendaki. Perilaku siswa normatif pada saat UNBK termasuk perilaku terbuka, terwujud dari perilaku siswa hadir sebelum UNBK dimulai kemudian menunggu di depan ruangan ujian mereka masing-masing, memakai pakaian yang rapi, memakai kokarde peserta ujian dan tidak keluar masuk selama ujian berlangsung. Perilaku normatif dipengaruhi oleh faktor predisposisi yakni karena adanya nilai atau sesuatu yang dianggap baik atau buruk oleh masyarakat. Siswa mengerti dan sangat memahami bahwa datang sebelum ujian dimulai berpakaian rapi dan berperilaku sesuai aturan adalah perilaku yang dianggap baik oleh orang lain. Perilaku ini terbentuk melalui kebiasaan, siswa datang tepat waktu pada saat ujian merupakan perilaku yang terbentuk melalui kebiasaan yang telah mereka lakukan di sekoleh sehingga sudah terbiasa datang tepat waktu.

Perilaku ini disebabkan oleh faktor atribusi eksternal. Siswa hadir tepat sebelum UNBK dimulai karena siswa mematuhi norma atau aturan yang tertera pada Prosedur Operasional Standar (POS) Ujian Nasional Berbasis Komputer (UNBK). Agar siswa tidak lupa mengenai tata tertib peserta ujian panitia UNBK meletakan berner yang berisi tata tertib di depan ruang ujian siswa selain itu panitia juga menempelkan kertas yang berisi tata tertib di jendela ruangan siswa. Hal ini membuat siswa berperilaku mematuhi peraturan UNBK. 


\section{Perilaku siswa mandiri pada saat ujian berlangsung}

Perilaku mandiri menurut (Parker: 2005. 227) merupakan kepercayaan terhadap diri sendiri, perilaku yang memungkinkan seseorang untuk bertindak bebas, benar dan bermanfaat, berusaha melakukan sesuatu dengan jujur dan benar atas dorongan dirinya sendiri dan kemampuan mengatur diri sendiri. Perilaku siswa mandiri pada saat UNBK berlangsung terwujud dari siswa percaya diri pada saat ujian berlangsung terlihat dari perilaku siswa fokus pada soal ujian yang ditampilkan di komputer mereka masing-masing, jika ada soal yang sulit mereka tidak bertanya kepada teman sebelah melainkan meninggalkannya terlebih dahulu kemudian mengulang membaca soal sampai menemukan jawaban yang lebih menepati, waktu ujian dimanfaatkan dengan sebaik mungkin sehingga tidak ada siswa yang izin keluar dan tidur di dalam kelas.

Perilaku siswa mandiri pada saat ujian berlangsung dipengaruhi oleh faktor predisposisi. keyakinan siswa untuk mempu menjawab soal UNBK dengan benar karena mereka sudah melakukan berbagai persiapan seperti serius pada saat belajar tambahan dan mengikuti les sehingga ia percaya diri pada saat ujian berlangsung. Perilaku mandiri pada saat ujian berlangsung terbentuk oleh insight yaitu siswa memahami bahwa jika tingkat kehadiran tinggi pada saat belajar tambahan, belajar dengan serius, mengikuti bimbingan belajar di tempat les dan mengulang kembali belajar dirumah, maka mereka akan mampu menjawab soal UNBK dengan benar dan mendapatkan nilai yang bagus. Perilaku ini disebabkan oleh faktor atribusi internal. Perilaku siswa mandiri pada saat Ujian Nasional Berbasis Komputer (UNBK) dikarenakan siswa telah melakukan berbagai persiapan dalam menghadapi UNBK diantaranya; mengikuti belajar tambahan dengan serius, mengulang pembelajaran di rumah, dan selain itu mereka juga mengikuti bimbingan belajar di GAMA dan di GO. Persiapan siswa yang matang sehingga siswa terdorong untuk percaya diri dalam menjawab soal ujian, memaksimalkan waktu ujian dengan sebaik mungkin, tidak mau bertanya atau berdiskusi dengan teman yang lain karena merekan mempunyai persepsi belum tentu teman tersebut memiliki jawaban yang benar.

\section{Perilaku siswa menyimpang pada saat ujian}

Perilaku menyimpang menurut Dwikurnia (dalam Zanden: 2004) adalah perilaku yang dilakukan oleh sejumlah besar orang dianggap sebai hal yang tercela. Perilaku menyimpang pada saat UNBK berlangsung pada saat ujian merupakan perilaku siswa yang tidak sesuai dengan peraturan UNBK. Perilaku siswa menyimpang termasuk perilaku terbuka yang terwujud dari; 1) perilaku siswa datang terlambat, siswa yang lain sudah memulai ujian sedangkan siswa yang terlambat masih berjalan santai menuju ruang ujian, 2) perilaku siswa tidur pada saat ujian berlangsung merupakan perilaku yang tidak efisien, membuang-buang waktu untuk sesuatu yang tidak penting, 3) perilaku melihat kunci jawaban merupakan perilaku curang pada saat ujian berlangsung.

Perilaku siswa menyimpang pada saat ujian dipengaruhi oleh faktor pendukung yakni tersedia sarana prasarana. Perilaku siswa melihat kunci jawaban pada saat ujian berlangsung karena adanya faktor pendukung seperti kunci jawaban dari seorang lain serta siswa juga memiliki handphone untuk memudah siswa dalam mengakses kunci jawaban tersebut. Perilaku ini terbentuk karena adanya model atau perilaku seseorang yang mereka tiru. Siswa berani melihat kunci jawaban pada saat ujian karena melihat dan mendengar pengalaman kakak kelas mereka yang melihat kunci jawaban pada saat UNBK sehingga mereka meniru perilaku tersebut. Perilaku ini disebabkan atribusi eksternal Perilaku siswa terlambat dan melihat kunci jawaban disebabkan oleh faktor atribusi eksternal. Siswa datang terlambat ke sekolah bukan karena keinginan dirinya tetapi disebabkan olef faktor diluar dirinya seperti menunggu ojek terlebih dahulu, mengantarkan kakak ke rumah sakit dan lain-lain. Perilaku 
siswa melihat kunci jawaban disebabkan oleh pengaruh teman dan orang yang membuat dan mengedarkan kunci jawaban tersebut. Mereka mempercayai kunci tersebut karena tidak ada pilihan lain untuk menjawab soal ujian.

\section{Perilaku siswa bergantung kepada orang lain}

Perilaku bergantung merupakan perilaku yang tidak mampu mengendalikan dirinya sendiri dalam merencanakan dan membuat keputusan penting. Perilaku bergantung pada saat Ujian Nasional Berbasis Komputer (UNBK) termasuk bentuk perilaku terbuka dapat terlihat dari siswa melakukan diskusi mengenai rumus dengan teman yang ada disebelahnya, dan siswa bertanya mengenai jawaban yang tidak diketahui atau diragukan kepada teman yang menurut mereka memiliki kemampuan yang lebih. Perilaku siswa bergantung kepada orang lain dipengaruhi oleh Faktor presdiposisi yang terwujud dari kepercayaan. Siswa percaya kepada teman akan membantu mereka dalan menjawab soal UNBK. Perilaku ini terbentuk karena adanya kebiasaan. Siswa yang bergantung pada saat ujian karena ia tidak melakukan persiapan untuk menghadapi ujian sehingga ia selalu bertanya dan bergantung kepada orang lain setiap kali melaksanakan ujian.

Perilaku ini disebabkan oleh dua faktor yaitu faktor atribusi internal dan faktor atribusi eksternal. Faktor atribusi internal disebabkan yaitu karena siswa tidak memiliki persiapan yang matang untuk menghadapi ujian nasional. Sehingga hal inilah mendorong mereka untuk bergantung kepada teman yang lain agar dapat menjawab soal UNBK dengan cara berdiskusi dan bertanya selama ujian berlangsung. Faktor atribusi eksternal disebabkan yaitu karena pengawas membiarkan siswa melakukan diskusi dan bertanya antara satu dengan yang lainnya dengan syarat pelan-pelan jika bersuara keras pengawas menegurnya. Tindakan pengawas yang memberikan peluang kepada siswa untuk semakin bergantung kepada teman yang lain pada saat ujian.

Adapun hasil Ujian Nasional Berbasis Komputer (UNBK) akan dijelaskan pada tabel dibawah ini.

Tabel 3. Hasil Ujian Nasional Berbasis Komputer Siswa Jurusan IPA Tahun 2018

\begin{tabular}{|c|c|c|c|c|c|c|}
\hline \multirow{2}{*}{ No } & \multicolumn{3}{|c|}{ Nilai Rata-rata Mata Pelajaran Umum } & \multicolumn{2}{|c|}{$\begin{array}{c}\text { Nilai Rata-rata Mata } \\
\text { Pelajaran Pilihan }\end{array}$} \\
\cline { 2 - 7 } & $\begin{array}{c}\text { Bahasa } \\
\text { Indonesia }\end{array}$ & $\begin{array}{c}\text { Bahasa } \\
\text { Inggris }\end{array}$ & Matematika & Biologi & Kima & Fisika \\
\hline 1 & 70.90 & 46.52 & 40.87 & 55.56 & 53.75 & 44.41 \\
\hline
\end{tabular}

(Sumber: TU SMAN 3 Pariaman)

Tabel 4. Hasil Ujian Nasional Berbasis Komputer Siswa Jurusan IPS Tahun 2018

\begin{tabular}{|c|c|c|c|c|c|c|}
\hline \multirow{2}{*}{ No } & \multicolumn{2}{|c|}{ Nilai Rata-rata Mata Pelajaran Umum } & \multicolumn{2}{|c|}{$\begin{array}{c}\text { Nilai Rata-rata Mata } \\
\text { Pelajaran Pilihan }\end{array}$} \\
\cline { 2 - 7 } & $\begin{array}{c}\text { Bahasa } \\
\text { Indonesia }\end{array}$ & $\begin{array}{c}\text { Bahasa } \\
\text { Inggris }\end{array}$ & Matematika & Sosiologi & Ekonomi & Geografi \\
\hline 1 & 62.10 & 37.80 & 29.96 & 55.37 & 48.04 & 52.82 \\
\hline
\end{tabular}

(Sumber: TU SMAN 3 Pariaman)

Berdasarkan kedua tabel di atas dapat kita lihat bahwa rata-rata hasil Ujian Nasional Berbasis Komputer (UNBK) siswa jurusan IPA lebih tinggi dari pada hasil Ujian Nasional 
Nadia Muspita Sari, Erianjoni, Ike Sylvia Perilaku Siswa Menghadapi UNBK di SMAN 3 Pariaman Tahun 2018

siswa jurusan IPS. Ujian Nasioanal sangat berpengaruh terhadap pendidikan siswa selanjutnya, yaitu diterima atau tidak diperguruan tinggi. Berikut tabel siswa jurusan IPA dan IPS yang lulus di perguruan tinggi.

Tabel 5. Siswa jurusan IPA dan IPS yang Lulus Perguruan Tinggi

\begin{tabular}{|c|c|c|c|c|c|}
\hline \multirow{2}{*}{ No } & Jurusan & \multirow{2}{*}{\begin{tabular}{c} 
Jumlah \\
Keseluruhan \\
\cline { 4 - 6 }
\end{tabular}} & & \multicolumn{3}{|c|}{ Diterima di Perguruan Tinggi } \\
\cline { 4 - 6 } & Siswa & PTN & PTS & Jumlah \\
\hline 1 & IPA & 146 & 40 & 9 & 49 \\
\hline 2 & IPS & 179 & 24 & 4 & 28 \\
\hline
\end{tabular}

(Sumber: TU SMAN 3 Pariaman)

Berdasarkan tabel di atas dapat kita lihat bahwa; Siswa jurusan IPA berjumlah 146 orang yang diterima di perguruan tinggi berjumlah 49 orang. Siswa jurusan IPS berjumlah 179 orang, yang diterima diperguruan tinggi hanya 28 orang. Dapat kita simpulkan bahwa siswa jurusan IPA lebih banyak ditrima di perguruan tinggi dibandingkan siswa jurusan IPS.

\section{Pembahasan}

Perilaku siswa menghadapi Ujian Nasional Berbais Komputer (UNBK) di SMA Negeri 3 Pariaman tahun 2018 dianalisis dengan teori atribusi (attribution theory) oleh Fritz Heider. Teori ini memiliki argumentasi bahwa perilaku seseorang itu ditentukan oleh kombinasi antara kekuatan internal (internal forces) yaitu faktor-faktor yang berasal dari dalam diri seseorang misalnya kemampuan, pengetahuan atau usaha, sedangkan kekuatan eksternal (eksternal forces) yaitu faktor-faktor yang berasal dari luar misalnya keberuntungan, kesempatan dan lingkungan. Disposition attribution atau penyebab internal mengacu pada aspek perilaku individu, sesuatu yang ada dalam diri seseorang seperti sifat pribadi, persepsi diri, kemampuan motivasi. Situational attribution atau penyebab eksternal mengacu pada lingkungan yang mempengaruhi perilaku, seperti kondisi sosial, nilai sosial, pandangan masyarakat. Teori Atribusi mengembangkan konsep cara-cara penilaian manusia yang berbeda, tergantung pada makna yang dihubungkan dengan perilaku tertentu. Perilaku siswa positif terdiri dari empat jenis perilaku yaitu; a) perilaku siswa valisional terhadap UNBK, b) aktif pada saat belajar tambahan, c) perilaku normatif menghadapi UNBK, d) perilaku mandiri pada saat ujian berlangsung. Sedangkan perilaku negatif terdiri dari; a) perilaku stereotip terhadap UNBK, b) pasif pada saat belajar tambahan, c) perilaku menyimpang pada saat ujian, d) perilaku bergantung pada saat ujian berlangsung. Perilaku siswa positif dipengaruhi oleh dua faktor yaitu faktor internal dan faktor eksternal. Faktor internal yaitu faktor yang berasal dalam diri siswa, seperti adanya motivasi yang besar terdapat di dalam diri siswa untuk mencapai tujuannya yaitu keinginan untuk mendapatkan nilai Ujian Nasional Berbasis Komputer (UNBK) dan diterima di perguruan tinggi favorit. Faktor eksternal yaitu faktor yang berasal dari luar diri siswa yaitu lingkungan sosial siswa, seperti adanya motivasi dari guru untuk serius pada saat belajar tambahan dengan cara menginovasikan model pembelajaran sehingga siswa termotivasi untuk belajar. Selain itu siswa juga mendapatkan motivasi dari orang tua dalam bentuk memfasilitasi mereka untuk mengikuti bimbingan belajar di GAMA dan GO. Berdasarkan kedua faktor di atas faktor yang memiliki kekuatan yang paling besar dalam mempengaruhi perilaku positif siswa dalam menghadapi UNBK di SMAN 3 Pariaman tahun 2018 adalah faktor internal yakni motivasi dalam diri siswa itu sendiri.

Perilaku siswa negatif juga dipengaruhi oleh dua faktor yaitu faktor internal dan faktor eksernal. Faktor internal yang mempengaruhi perilaku siswa negatif yaitu siswa tidak 
memiliki keinginan untuk melanjutkan pendidikan ke perguruan tinggi, mereka lebih memilih untuk bekerja setelah tamat SMA. Sedangkan faktor eksternal yang mempengaruhi perilaku siswa yaitu teman, guru, dan orang tua. Teman sangat besar mempengaruhi perilaku siswa seperti adanya pengaruh dalam pembentukan stereotipe bahwa UNBK hanya sebagai formalitas yang menentukan kelulusan adalah pihak sekolah, dan sekolah pasti meluluskan karena demi nama baik sekolah, dengan adanya stereotip seperti ini sehingga tinggkat kehadiran siswa rendah pada saat belajar tambahan, pasif dalam proses belajar, melanggar aturan UNBK dan bergantung kepada orang lain dalam menjawab soal ujian. Selain teman guru dan orang tua juga mempengaruhi perilaku siswa, dalam proses pembelajaran guru kurang melakukan inovasi model dan metode pembelajaran sehingga siswa kurang termotivasi untuk belajar. Sementara orang tua juga terlalu sibuk dengan pekerjaan masingmasing sehingga anak kurang mendapatkan perhatian mengenai pendidikannya. Berdasarkan kedua faktor di atas faktor yang memiliki kekuatan yang paling besar dalam mempengaruhi perilaku negatif siswa dalam menghadapi UNBK di SMAN 3 Pariaman tahun 2018 adalah faktor eksternal yakni faktor yang berasal dari luar diri siswa seperti teman, guru, dan orang tua.

Perilaku siswa yang positif disebabkan karena siswa memiliki tujuan yakni lulus di perguruan tinggi yang mereka inginkan, sehingga siswa berperilaku aktif pada saat belajar tambahan, siswa mentaati seluruh aturan UNBK, serta siswa percaya diri dan memanfaatkan waktu dengan baik pada saat ujian berlangsung. Perilaku ini ditunjukan oleh mayoritas siswa jurusan IPA. Perilaku siswa yang negatif disebabkan karena siswa tidak memiliki tujuan untuk melanjutkan pendidikan ke perguruan tinggi dan menganggap UNBK hanya sebagai formalitas, sehingga siswa berperilaku pasif pada saat belajar tambahan, melanggar peraturan UNBK, serta bergantung kepada orang lain untuk menjawab soal ujian. Perilaku positif dan perilaku negatif mempengaruhi hasil Ujian Nasional Berbasis Komputer (UNBK) dan jumlah siswa yang diterima di perguruan tinggi. Siswa jurusan IPA memperoleh hasil UNBK lebih tinggi dibandingkan siswa jurusan IPS selain itu siswa jurusan IPA lebih banyak diterima di perguruan tinggi dibandingkan siswa jurusan IPS.

UNBK memang tidak terkait dengan kelulusan siswa di sekolah tetapi nilai UNBK berdampak pada pertama pearangkingan sekolah, kedua nilai UNBK dipertimbangkan untuk masuk perguruan tinggi, yang ketiga berkaitan dengan integritas sekolah tentang nilai kejujuran. Pihak sekolah SMA Negeri 3 Pariaman lebih memfokuskan kepada mekanisme teknik penyelenggaran UNBK dan terlena dengan kemudahan yang dimiliki oleh UNBK. Sehingga pihak sekolah secara tidak sadar melupakan tujuan UNBK yang sesungguhnya diharapkan untuk siswa yakni melanjutkan ke pendidikan selanjutnya. Salah satu manfaat UNBK adalah meminimalisir kecurangan pada saat ujian nasional tetapi manfaat tersebut belum terwujud dalam pelaksanaan UNBK di SMAN 3 Kota Pariaman pada tahun 2018. Masih ada siswa yang melakukan kerjasama, bertanya, dan melihat kunci jawaban pada saat UNBK berlangsung.

\section{Kesimpulan}

Berdasarkan hasil penelitian yang penulis lakukan di SMA Negeri 3 Kota Pariaman adalah sebagai berikut;

1. Perilaku siswa dkelompokan ke dalam dua bentuk perilaku yaitu perilaku positif dan perilaku negatif. Perilaku positif terdiri dari; perilaku siswa valisional terhadap UNBK, aktif pada saat belajar tambahan, perilaku normatif menghadapi UNBK, dan perilaku mandiri pada saat ujian berlangsung. Sedangkan perilaku negatif terdiri dari; 
Nadia Muspita Sari, Erianjoni, Ike Sylvia Perilaku Siswa Menghadapi UNBK di SMAN 3 Pariaman Tahun 2018

perilaku stereotip terhadap UNBK, pasif pada saat belajar tambahan, perilaku menyimpang pada saat ujian, dan perilaku bergantung pada saat ujian berlangsung.

2. Perilaku positif ditunjukan oleh mayoritas siswa yang berasal dari jurusan IPA sedangkan perilaku negatif ditunjukan oleh mayoritas siswa yang berasal dari jurusan IPS. Perilaku positif dan perilaku negatif mempengaruhi hasil UNBK dan jumlah siswa yang diterima di perguruan tinggi. Siswa jurusan IPA memperoleh hasil UNBK lebih tinggi dibandingkan siswa jurusan IPS selain itu siswa jurusan IPA lebih banyak diterima di perguruan tinggi dibandingkan siswa jurusan IPS.

3. Perilaku siswa posif didominasi oleh pengaruh atribusi internal yaitu motivasi, kemampuan, pengetahuan dan usaha sedangkan perilaku siswa negatif didominasi oleh kekuatan atribusi eksternal yaitu keberuntungan, kesempatan dan lingkungan.

\section{Daftar Pustaka}

Ahmad, Kholid. (2012). Promosi Kesehatan. Jakarta: Rajawali Pers

Arivin, Imron. (1996). Penelitian Kualitatif dalam Ilmu-Ilmu Sosial. Malang: Kalimasahada Press.

Basrowi dan Suwandi. (2008). Memahami Penelitian Kualitatif. Jakarta: Rineka Cipta.

Bumeister dan Busman. 2011. Social Psychology and Human Nature. Belmont: Cengage Learning

Hidayati. (2002). Pendidikan Ilmu Pengetahuan di Sekolah Dasar. Yogyakarta: FIP UNY

J. Meleong, lexy. (2012). Metodologi Penelitian Kualitatif. Bandung: Remaja Rosdakarya

Jogiyanto. (2007). Sistem Informasi Keperlakuan. Edisi Revisi. Yogyakarta: Andi Offet

Kemdikbud. (2015). Materi Konferensi Pers tanggal 23 Januari 2015: Kebijakan Perubahan Ujian nasional. http://www.litbang.kemdikbud.go.id Diakses pada tanggal 13 April 2017)

Mathew, Miles dan Michael Huberman. (1992). Analisis Data Kualitatif. Jakarta: UI-Press.

Miftah, Toha. (2003). Prilaku Organisasi. Jakarta: Raja Grafindo Persada.

Notoatmodjo. (2014). Ilmu Perilaku Kesehatan. Jakarta: Rineka cipta

Parker. (2005). Menumbuhkan Kemandirian dan Harga Diri Anak. Jakarta: Prestasi Pustakarya

Peraturan Menteri Pendidikan dan Kebudayaan Republik Indonesia Nomor 5 Tahun 2015 tentang Kriteria Kelulusan Peserta Didik dari Satuan Pendidikan dan Penyelenggaraan Ujian Sekolah/Madrasah/Pendidikan Kesetaraan dan Ujian nasional.

Prastowo, Andi. (2016). Metode Penelitian Kualitatif dalam Perspektif Rancangan Penelitian.Yogjakarta: Ar-Ruzz Media.

Sugiyono. (2016). Metode Penlitian Kombinasi. Bandung: Alfabeta

Sukmadinata, Nana Syaodih. Metode Penelitian Pendidikan. Bandung: Remaja Rosdakarya.

Zanden, James. (1998). The Social Experience An Introduction to Sociology. New York: Random House. 